\title{
Projektowanie i realizacja badań funkcjonalności bibliotek akademickich we Włoszech. Gruppo Interuniversitario per il Monitoraggio dei sistemi bibliotecari di Ateneo - studium przypadku
}

\begin{abstract}
Streszczenie. Gruppo Interuniversitario per il Monitoraggio dei sistemi bibliotecari di Ateneo (GIM) to organizacja międzyuczelniana, która od 2000 roku przeprowadza regularne badania funkcjonalności włoskich bibliotek akademickich. Grupę tworzą przedstawiciele 16 znaczących uczelni. Wyniki badań publikowane na stronie internetowej organizacji stanowią swoistą bazę danych na temat funkcjonowania współczesnych bibliotek akademickich we Włoszech oraz tendencji rozwojowych włoskiego bibliotekarstwa, są też interesujące pod względem porównawczym. Celem artykułu jest zreferowanie działalności grupy GIM na przestrzeni kilkunastu lat, przedstawienie najważniejszych założeń projektu, prezentacja stosowanych metod badawczych oraz ukazanie, w jaki sposób podejmowane inicjatywy wpisują się w szerszy kontekst badań funkcjonalności bibliotek podejmowanych w całej Europie, również w Polsce.
\end{abstract}

SŁowA KLUCzowe: badania funkcjonalności bibliotek, standardy oceny bibliotek akademickich, współczesne biblioteki włoskie.

Biblioteki akademickie są coraz częściej traktowane jako ważny element oferty edukacyjnej uczelni. Wzrasta ich rola jako instytucji wspomagających procesy dydaktyczne i badania naukowe oraz organizujących dostęp do informacji naukowej. Jednocześnie są one postrzegane jako organizacje usługowe, których użytkownicy utożsamiani są z klientami. Wszystkie te aspekty wpływają na rosnącą potrzebę ciągłego ulepszania inicjatyw podejmowanych przez biblioteki akademickie i dostosowywania ich do potrzeb środowiska uczelnianego. Pomocne $\mathrm{w}$ ustaleniu 
efektywności działań realizowanych przez biblioteki w celu zapewnienia użytkownikom optymalnej obsługi może być przeprowadzanie regularnej oceny bibliotek według określonych standardów funkcjonalności. Jak pisze Ewa Głowacka:

Funkcjonalność badamy wtedy, gdy naszym celem jest ustalenie efektywności dostarczania przez bibliotekę usług oraz skuteczności przeznaczenia i wykorzystania zasobów celem świadczenia tych usług. Pomiarów funkcjonalności dokonuje się na drodze obliczania wskaźników funkcjonalności (performance indicators). Staramy się je dobrać zgodnie z celem prowadzenia badań. Informacja płynąca z analizy takich wskaźników pozwala na wymierną ocenę rezultatów działania biblioteki oraz ich doskonalenie. Odpowiednio dobrane wskaźniki mogą bowiem pokazać różne aspekty działania systemu bibliotecznego, dając skwantyfikowany materiał do dalszych analiz ${ }^{1}$.

Szczegółowo opracowany zbiór wskaźników funkcjonalności dla bibliotek akademickich na całym świecie dostępny jest w zaleceniach IFLA. Wskaźniki zostały zaprezentowane w 1996 roku przez Roswithę Poll i Petera te Boekhorsta, pracowników biblioteki w Monachium, i ukazały się w formie książki będącej rezultatem wieloletnich prac obojga autorów w wyspecjalizowanej sekcji IFLA². Międzynarodową normą dotyczącą wszystkich typów bibliotek, obejmującą wskaźniki funkcjonalności jest norma ISO 11620, opracowana przez Komitet Techniczny ISO/TC 46 we współpracy z przedstawicielami IFLA. W wielu europejskich krajach powstały narodowe programy cyklicznie oceniające jakość i funkcjonalność bibliotek akademickich, takie jak niemiecki BIX (Bibliotheksindex), brytyjski HELMS (UK Higher Education Library Management Statistics), szwedzki Swedish Quality Handbook ${ }^{3}$ oraz polski projekt Analiza funkcjonowania bibliotek naukowych w Polsce (AFBN), realizowany od 2001 roku przez Zespół ds. Standardów dla Bibliotek Naukowych. We Włoszech oceną pracy bibliotek akademickich zajęła się organizacja Gruppo Interuniversitario per il Monitoraggio dei sistemi bibliotecari di Ateneo (GIM) - Międzyuczelniana Grupa Monitorująca Akademickie Systemy Biblioteczne. Do grupy należą przedstawiciele 16 znaczących włoskich uczelni: Alma mater studiorum di Bologna, Politecnico di Milano,

${ }^{1}$ E. Głowacka, Narzędzia oceny funkcjonalności ustug biblioteczno-informacyjnych, w: Standardy biblioteczne. Praktyka, teoria, projekty, red. M. Wojciechowska, Gdańsk 2010, s. 129.

2 Por. T. Szmigielska, Standardy oceny bibliotek akademickich, Warszawa 2011, s. 59-70.

${ }^{3}$ Por. ibidem, s. 78-94. 
Politecnico di Torino, Università degli Studi dell'Insubria, Università degli Studi di Ferrara, Università degli Studi di Firenze, Università degli Studi di Milano, Università degli Studi di Milano-Bicocca, Università degli Studi di Modena e Reggio Emilia, Università degli Studi di Padova, Università degli Studi di Parma, Università degli Studi di Pavia, Università degli Studi di Perugia, Università degli Studi di Sassari, Università degli Studi di Siena, Università degli Studi di Trento. Większość z wymienionych zajmuje czołowe miejsca $\mathrm{w}$ corocznym rankingu najlepszych włoskich uczelni, przeprowadzanym przez społeczno-gospodarczy instytut badawczy Centro Studi Investimenti Sociali - CENSIS ${ }^{4}$ - ich pozycja na włoskim rynku edukacyjnym jest więc bardzo mocna. Zreferowana w artykule działalność grupy GIM oraz konkluzje płynące z kilkunastu już lat doświadczeń mogą być - jak się wydaje - przydatne także w Polsce.

Grupa zadaniowa GIM została utworzona w 2000 roku w celu przeprowadzenia badań statystycznych dotyczących funkcjonowania włoskich bibliotek akademickich oraz dokonania analizy porównawczej (benchmarkingu). Wcześniej we Włoszech badano funkcjonalność bibliotek, lecz były to analizy funkcjonowania poszczególnych jednostek, oparte na danych zebranych wyłącznie w obrębie jednej placówki, służące samoocenie. Obecnie GIM regularnie dokonuje analiz funkcjonalności włoskich bibliotek akademickich. Pozwalają one ustalić, jakie są tendencje rozwojowe usług bibliotecznych, a także jakie działania należy podjąć w celu ich udoskonalenia. Raporty z badań upubliczniane na stronie internetowej organizacji GIM stanowią swoistą bazę danych na temat funkcjonowania współczesnych włoskich bibliotek akademickich, zbierają wskaźniki dotyczące ich efektywności, wydajności i funkcjonalności, są interesujące pod względem porównawczym oraz ilustrują to, jak w ostatnim dziesięcioleciu zmieniała się praca bibliotek ${ }^{5}$.

Podstawowe cele badań przeprowadzanych przez GIM zostały sformułowane w pierwszym raporcie organizacji opublikowanym w 2003 roku. Są nimi:

- opracowanie metody oceny i monitorowania usług bibliotek akademickich we Włoszech z wykorzystaniem zaawansowanych metodologii oraz elementów benchmarkingu,

${ }^{4}$ Centro Studi Investimenti Sociali - CENSIS - instytut badań socjoekonomicznych we Włoszech, założony w 1961 roku. W ramach swojej działalności sporządza coroczny ranking uniwersytetów publikowany w przewodniku Grande Guida Università. Informacje dotyczące instytutu są dostępne na jego stronie internetowej. Zob. Centro Studi Investimenti Sociali - CENSIS [online], [dostęp: 22.07.2013], dostępny w internecie: http://www.censis.it/1.

5 Por. L'attivita' del Gruppo Interuniversitario per il Monitoraggio dei Sistemi Bibliotecari di Ateneo, w: Rapporto sulle biblioteche Italiane 2009-2010, red. V. Ponzani, Roma 2010, s. 112. 
- pozyskanie danych do bazy komputerowej w celu opracowania wskaźników i standardów dla bibliotek akademickich we Włoszech,

- prowadzenie regularnych ankiet i analiz porównawczych ich wyników,

- opracowanie, publikowanie i rozpowszechnianie raportów końcowych,

- efekt: polepszenie jakości usług oferowanych użytkownikom przez biblioteki akademickie we Włoszech ${ }^{6}$.

Wymienione cele były później modyfikowane i uzupełniane, ale ich ogólny zarys pozostał taki sam.

Pierwsze badania zostały przeprowadzone przez organizację GIM przy wsparciu CNVSU - Comitato Nazionale per la Valutazione del Sistema Universitario del Ministero dell'Istruzione, dell'Università e della Ricerca (Narodowego Komitetu Oceniającego Systemy Uniwersyteckie powołanego przez Ministerstwo Nauki, Edukacji i Wyższych Uczelni). Opatrzono je nazwą: Misurazione e valutazione dell'offerta bibliotecaria degli Atenei Italiani (Pomiar i ocena oferty bibliotek uczelni wyższych we Włoszech). W przeprowadzeniu badań wzięło udział osiem bibliotek należących do: Alma mater studiorum di Bologna, Università degli Studi di Firenze, Università degli Studi di Milano-Bicocca, Università degli Studi di Padova, Università degli Studi di Parma, Politecnico di Torino, Università degli Studi di Trento, Servizio biblioteche del Comune di Padova. Sieć bibliotek miejskich w Padwie wymieniona jako ostatnia - jest jedynym przedstawicielem bibliotek publicznych, który wziął udział w projekcie. Proces badawczy podzielono na następujace fazy:

- zdefiniowanie wskaźników, jakie mają zostać opracowane podczas przeprowadzania badań, oraz określenie metod pomiaru,

- konstrukcja kwestionariusza ankiety,

- przygotowanie odpowiedniego oprogramowania,

- przeprowadzenie badań,

- przetwarzanie danych, podsumowanie ankiety i rozpowszechnianie wyników.

Bardzo ważne dla uczestników pierwszej edycji projektu było opracowanie zestawu odpowiednich wskaźników oraz metod pomiaru i oceny, które odpowiadałyby warunkom i oczekiwaniom wszystkich bibliotek mających podlegać badaniu.

${ }^{6}$ GIM - Gruppo Interuniversitario per il Monitoraggio dei sistemi bibliotecari di Ateneo, Gli obiettivi [online], [dostęp: 5.12.12], dostępny w internecie: http://www. gimsba.it/node/2. 
Przed wdrożeniem odpowiednich metod pomiaru i oceny zapoznano się z powstałymi wcześniej materiałami dotyczącymi standardów oceny bibliotek, narodowymi i międzynarodowymi, takimi jak:

- projekt MURST - pierwsza próba dokonania pomiaru i oceny standardów bibliotek akademickich we Włoszech przeprowadzona w 1999 roku, udokumentowana w raporcie MURST, Programma di ricerca misurazione e valutazione delle biblioteche universitarie: rapporto preliminare del gruppo di ricerca,

- projekt LIBECON,

- norma ISO (Information and documentation - Library Performance Indicators, 1998),

- norma ISO/FDIS 2789 (Information and documentation - International library statistics, 2002),

- publikacje: Linee guida per la valutazione delle biblioteche universitarie: edizione italiana di Measuring Quality, wydana w 1999 roku przez organizację AIB, przy współpracy IFLA; Performance: a Practical Approach, wydana w 1990 roku przez American Library Association; Library performance indicators and library management tools, wydana w 1995 roku przez Komisję Europejską i Dyrektorat Generalny w Luksemburgu.

W organizacji GIM powołano też specjalną komisję ekspertów, osób posiadających doświadczenie w ocenianiu standardów akademickich. Ich wskazówki i obserwacje służyły pomocą w odpowiednim zdefiniowaniu metod pomiaru i oceny, przydatnych w planowanych badaniach. Każda z definicji poddawana była testowi czterech pytań, na które odpowiadali członkowie komisji ekspertów. Pytania brzmiały:

- Jak ważne są niniejsze dane w systemie pomiaru i oceny włoskich bibliotek akademickich opartym na benchmarkingu?

- Czy sformułowana definicja jest w którymś miejscu niezrozumiała lub niejasna? Jeśli tak, to gdzie i dlaczego?

- Czy niniejsze dane znajdują się w systemie pomiaru na waszej uczelni?

- Prośba o ewentualne sugestie.

Z otrzymanych odpowiedzi wynikało, że w przeprowadzanych analizach należy zwrócić szczególną uwagę na działalność bibliotek cyfrowych, zarówno pod kątem źródeł elektronicznych, jak i pod kątem użytkowników zdalnych. Podkreślano również potrzebę otrzymywania danych porównawczych dotyczących zautomatyzowanych systemów i baz danych bibliotek tak często jak to możliwe. 
Po zakończeniu fazy testów stworzono sekcje tematyczne zawierające grupy zagadnień mających podlegać badaniu:

0 . System biblioteczny

1. Użytkownicy

2. Dostarczanie dokumentów

3. Przestrzeń

4. Godziny otwarcia

5. Personel

6/7. Przychody i koszty

8. Usługi techniczne - w obrębie działalności back office

9. Usługi publiczne - w obrębie działalności front office.

Do wymienionych sekcji tematycznych zaplanowano dostosowanie odpowiednich wskaźników, według których miały być wykonane pomiary. W tym celu dokonano przeglądu literatury fachowej prezentującej różne zestawienia wskaźników. Przeprowadzono także analizę wskaźników używanych do tej pory do pomiaru i oceny na uczelniach biorących udział w projekcie. W rezultacie utworzono "archiwum wskaźników” skonstruowane w formie bazy danych. Każdy ze 193 wskaźników funkcjonujących w archiwum został zaprezentowany według schematu:

- kod identyfikacyjny,

- nazwa,

- definicja,

- metoda pomiaru,

- źródło pochodzenia,

- zalecenia dotyczące jego konstrukcji,

- obszary zastosowań,

- funkcja oceniająca.

Podczas prac wyróżniono także pięć obszarów strukturalnych, do których miały się odnosić wskaźniki ostatecznie wykorzystane w badaniu:

- dostępność - wskaźniki uwzględniające łatwość bezpośredniego dostępu do przestrzeni fizycznej biblioteki i jej zasobów, ilość udostępnionego dla użytkownika miejsca;

- skuteczność, użyteczność, innowacyjność - wskaźniki uwzględniające usługi dla użytkowników, szczególnie te, które wykorzystują zasoby technologiczne;

- efektywność, wydajność, ekonomiczność - wskaźniki uwzględniające ekonomiczną stronę funkcjonowania biblioteki, pozwalające ocenić ostrożność bibliotek i systemów bibliotecznych w zarządzaniu kosztami i wpływami, mogące nawiązywać do elementów związanych z zasobami ludzkimi, finansowymi, terminami FTE (full-time equivalent), 
- ważność bibliotek na uczelniach, którym podlegają - wskaźniki pozwalające na ocenę organizacji i zarządzania w bibliotece i ich wpływu na złożoną organizację całego uniwersytetu,

- rentowność majątku, istotność oferowanych zasobów - wskaźniki oceniające bibliotekę w sposób globalny, uwzględniające kwestie usług dla użytkowników, politykę kolekcji tradycyjnych i cyfrowych, przewidywanie potrzeb użytkowników, według kryteriów ciągłego doskonalenia jakości.

Ostatecznie wybrano 40 wskaźników: osiem dotyczących kategorii dostępności, dziewięć - skuteczności, użyteczności, innowacyjności, osiem efektywności, wydajności, ekonomiczności, pięć - ważności bibliotek na uczelniach, którym podlegają dziesięć - rentowności majątku, istotności oferowanych zasobów. Trzydzieści cztery z nich zaczerpnięto z literatury fachowej, sześć stworzono na potrzeby projektu GIM. Wszystkie z wymienionych wskaźników wykorzystano do badań bibliotek, a 18 z nich do badań systemów bibliotecznych SBA (Sistema Bibliotecario di Ateneo), czyli uczelnianych systemów bibliotecznych, składających się z sieci bibliotek wydziałowych.

Tabela. Zestawienie wskaźników obliczanych w badaniach Gruppo Interuniversitario per il Monitoraggio dei sistemi bibliotecari di Ateneo

\begin{tabular}{|c|l|c|c|c|}
\hline $\mathrm{Nr}$ & \multicolumn{1}{|c|}{ Nazwa } & $\begin{array}{c}\text { Obszar } \\
\text { strukturalny }\end{array}$ & $\begin{array}{c}\text { Ankieta } \\
\text { "Biblioteca” }\end{array}$ & $\begin{array}{c}\text { Ankieta } \\
\text { SBA }\end{array}$ \\
\hline 1. & Średnia godzin otwarcia & dostępność & tak & tak \\
\hline 2. & $\begin{array}{l}\text { Powierzchnia biblioteki } \\
\text { przypadająca na jednego } \\
\text { użytkownika }\end{array}$ & dostępność & tak \\
\hline 3. & $\begin{array}{l}\text { Powierzchnia biblioteki do- } \\
\text { stępna dla użytkowników } \\
\text { jako procent całej powierzch- } \\
\text { ni biblioteki }\end{array}$ & dostępność & nie & tak \\
\hline 4. & $\begin{array}{l}\text { Liczba użytkowników na } \\
\text { jedno miejsce pracy w bi- } \\
\text { bliotece }\end{array}$ & dostępność \\
\hline 5. & $\begin{array}{l}\text { Powierzchnia regałów z wol- } \\
\text { nym dostępem przypadająca } \\
\text { na jednego użytkownika }\end{array}$ & dostępność & nie & tak \\
\hline 6. & $\begin{array}{l}\text { Powierzchnia regałów z wol- } \\
\text { nym dostępem jako procent } \\
\text { powierzchni wszystkich re- } \\
\text { gałów w bibliotece }\end{array}$ & dostępność & tak & tak \\
\hline 7. & Jednostki administracyjne & dostępność & nie & tak \\
\hline
\end{tabular}


Tab. cd.

\begin{tabular}{|c|c|c|c|c|}
\hline $\mathrm{Nr}$ & Nazwa & $\begin{array}{c}\text { Obszar } \\
\text { strukturalny }\end{array}$ & $\begin{array}{c}\text { Ankieta } \\
\text { „Biblioteca” }\end{array}$ & $\begin{array}{l}\text { Ankieta } \\
\text { SBA }\end{array}$ \\
\hline 8. & $\begin{array}{l}\text { Punkty obsługowe a jednost- } \\
\text { ki administracyjne }\end{array}$ & dostępność & nie & tak \\
\hline 9. & $\begin{array}{l}\text { Liczba użytkowników przy- } \\
\text { padających na jedno stano- } \\
\text { wisko komputerowe }\end{array}$ & $\begin{array}{l}\text { skuteczność, } \\
\text { użyteczność, } \\
\text { innowacyjność }\end{array}$ & nie & tak \\
\hline 10. & $\begin{array}{l}\text { Liczba stanowisk pracy } \\
\text { wyposażonych w komputer } \\
\text { jako procent ogólnej liczby } \\
\text { stanowisk pracy w bibliotece }\end{array}$ & $\begin{array}{l}\text { skuteczność, } \\
\text { użyteczność, } \\
\text { innowacyjność }\end{array}$ & tak & tak \\
\hline 11. & $\begin{array}{l}\text { Liczba wypożyczeń między- } \\
\text { bibliotecznych w przelicze- } \\
\text { niu na jednego użytkownika } \\
\text { (próśb o dostarczenie mate- } \\
\text { riałów z innej biblioteki) }\end{array}$ & $\begin{array}{l}\text { skuteczność, } \\
\text { użyteczność, } \\
\text { innowacyjność }\end{array}$ & nie & tak \\
\hline 12. & $\begin{array}{l}\text { Liczba wypożyczeń między- } \\
\text { bibliotecznych z zewnątrz } \\
\text { jako procent wszystkich } \\
\text { wypożyczeń międzybiblio- } \\
\text { tecznych }\end{array}$ & $\begin{array}{l}\text { skuteczność, } \\
\text { użyteczność, } \\
\text { innowacyjność }\end{array}$ & tak & tak \\
\hline 13. & $\begin{array}{l}\text { Przeszkoleni użytkownicy } \\
\text { jako procent ogólnej liczby } \\
\text { użytkowników }\end{array}$ & $\begin{array}{l}\text { skuteczność, } \\
\text { użyteczność, } \\
\text { innowacyjność }\end{array}$ & nie & tak \\
\hline 14. & $\begin{array}{l}\text { Liczba wypożyczeń między- } \\
\text { bibliotecznych jako procent } \\
\text { wszystkich wypożyczeń }\end{array}$ & $\begin{array}{l}\text { skuteczność, } \\
\text { użyteczność, } \\
\text { innowacyjność }\end{array}$ & tak & tak \\
\hline 15. & $\begin{array}{l}\text { Liczba logowań do baz da- } \\
\text { nych na jednego użytkow- } \\
\text { nika }\end{array}$ & $\begin{array}{l}\text { skuteczność, } \\
\text { użyteczność, } \\
\text { innowacyjność }\end{array}$ & nie & tak \\
\hline 16. & $\begin{array}{l}\text { Liczba godzin szkoleń prze- } \\
\text { znaczonych dla zapisanych } \\
\text { użytkowników }\end{array}$ & $\begin{array}{l}\text { skuteczność, } \\
\text { użyteczność, } \\
\text { innowacyjność }\end{array}$ & nie & tak \\
\hline 17. & $\begin{array}{l}\text { Zbiory opracowane kompu- } \\
\text { terowo jako procent ogólnej } \\
\text { liczby zbiorów }\end{array}$ & $\begin{array}{l}\text { skuteczność, } \\
\text { użyteczność, } \\
\text { innowacyjność } \\
\end{array}$ & tak & tak \\
\hline 18. & $\begin{array}{l}\text { Wydatki na zakup materia- } \\
\text { tów bibliotecznych na jedne- } \\
\text { go użytkownika }\end{array}$ & $\begin{array}{l}\text { efektywność, } \\
\text { wydajność, } \\
\text { ekonomiczność }\end{array}$ & nie & tak \\
\hline 19. & $\begin{array}{l}\text { Wydatki na zakup czaso- } \\
\text { pism drukowanych jako } \\
\text { procent całości wydatków na } \\
\text { materiały biblioteczne }\end{array}$ & $\begin{array}{l}\text { efektywność, } \\
\text { wydajność, } \\
\text { ekonomiczność }\end{array}$ & tak & tak \\
\hline
\end{tabular}


Tab. cd.

\begin{tabular}{|c|c|c|c|c|}
\hline $\mathrm{Nr}$ & Nazwa & $\begin{array}{c}\text { Obszar } \\
\text { strukturalny }\end{array}$ & $\begin{array}{c}\text { Ankieta } \\
\text { „Biblioteca” }\end{array}$ & $\begin{array}{l}\text { Ankieta } \\
\text { SBA }\end{array}$ \\
\hline 20. & $\begin{array}{l}\text { Wydatki na zakup źródeł } \\
\text { elektronicznych jako procent } \\
\text { całości wydatków na mate- } \\
\text { riały biblioteczne }\end{array}$ & $\begin{array}{l}\text { efektywność, } \\
\text { wydajność, } \\
\text { ekonomiczność }\end{array}$ & tak & tak \\
\hline 21. & $\begin{array}{l}\text { Całość wydatków biblioteki } \\
\text { na jednego użytkownika }\end{array}$ & $\begin{array}{l}\text { efektywność, } \\
\text { wydajność, } \\
\text { ekonomiczność }\end{array}$ & nie & tak \\
\hline 22. & $\begin{array}{l}\text { Wydatki biblioteki na per- } \\
\text { sonel / całość wydatków } \\
\text { biblioteki }\end{array}$ & $\begin{array}{l}\text { efektywność, } \\
\text { wydajność, } \\
\text { ekonomiczność }\end{array}$ & tak & tak \\
\hline 23. & $\begin{array}{l}\text { Wypożyczenia + wypożycze- } \\
\text { nia międzybiblioteczne na } \\
\text { zewnątrz biblioteki + usługa } \\
\text { „Document delivery” na } \\
\text { zewnątrz biblioteki / liczba } \\
\text { pracowników zatrudnionych } \\
\text { na pełen etat (FTE) }\end{array}$ & $\begin{array}{l}\text { efektywność, } \\
\text { wydajność, } \\
\text { ekonomiczność }\end{array}$ & tak & tak \\
\hline 24. & $\begin{array}{l}\text { Liczba nowych nabytków / } \\
\text { liczba personelu }\end{array}$ & $\begin{array}{l}\text { efektywność, } \\
\text { wydajność, } \\
\text { ekonomiczność }\end{array}$ & tak & tak \\
\hline 25. & $\begin{array}{l}\text { Liczba zbiorów / liczba per- } \\
\text { sonelu }\end{array}$ & $\begin{array}{l}\text { efektywność, } \\
\text { wydajność, } \\
\text { ekonomiczność }\end{array}$ & tak & tak \\
\hline 26. & $\begin{array}{l}\text { Pracownicy biblioteki jako } \\
\text { procent ogólnej liczby pra- } \\
\text { cowników uczelni }\end{array}$ & $\begin{array}{l}\text { rola biblioteki } \\
\text { na uczelni }\end{array}$ & nie & tak \\
\hline 27. & $\begin{array}{l}\text { Powierzchnia całkowita } \\
\text { biblioteki jako procent po- } \\
\text { wierzchni całkowitej uczelni }\end{array}$ & $\begin{array}{l}\text { rola biblioteki } \\
\text { na uczelni }\end{array}$ & nie & tak \\
\hline 28. & $\begin{array}{l}\text { Wydatki biblioteki jako pro- } \\
\text { cent ogólnych wydatków } \\
\text { całej uczelni }\end{array}$ & $\begin{array}{l}\text { rola biblioteki } \\
\text { na uczelni }\end{array}$ & nie & tak \\
\hline 29. & $\begin{array}{l}\text { Powierzchnia biblioteki } \\
\text { dostępna dla personelu EP } \\
\text { (Elevata Professionalità) jako } \\
\text { procent całości powierzchni } \\
\text { biblioteki dostępnej dla per- } \\
\text { sonelu }\end{array}$ & $\begin{array}{l}\text { rola biblioteki } \\
\text { na uczelni }\end{array}$ & nie & tak \\
\hline 30. & $\begin{array}{l}\text { Dysponowanie samodziel- } \\
\text { nym budżetem przez SBA }\end{array}$ & $\begin{array}{l}\text { rola biblioteki } \\
\text { na uczelni }\end{array}$ & nie & tak \\
\hline 31. & $\begin{array}{l}\text { Liczba użytkowników / licz- } \\
\text { ba pracowników zatrudnio- } \\
\text { nych na pełen etat (FTE) }\end{array}$ & $\begin{array}{l}\text { rentowność ma- } \\
\text { jątku, oferowa- } \\
\text { ne zasoby }\end{array}$ & nie & tak \\
\hline
\end{tabular}


Tab. cd.

\begin{tabular}{|c|c|c|c|c|}
\hline $\mathrm{Nr}$ & Nazwa & $\begin{array}{c}\text { Obszar } \\
\text { strukturalny }\end{array}$ & $\begin{array}{c}\text { Ankieta } \\
\text { „Biblioteca” }\end{array}$ & $\begin{array}{l}\text { Ankieta } \\
\text { SBA }\end{array}$ \\
\hline 32. & $\begin{array}{l}\text { Pracownicy z wyższym wy- } \\
\text { kształceniem zawodowym } \\
\text { jako procent pracowników } \\
\text { zatrudnionych na pełen etat }\end{array}$ & $\begin{array}{l}\text { rentowność ma- } \\
\text { jątku, oferowa- } \\
\text { ne zasoby }\end{array}$ & tak & tak \\
\hline 33. & $\begin{array}{l}\text { Liczba pracowników zatrud- } \\
\text { nionych na pełen etat (FTE) / } \\
\text { liczba punktów usługowych } \\
\text { w bibliotece }\end{array}$ & $\begin{array}{l}\text { rentowność ma- } \\
\text { jątku, oferowa- } \\
\text { ne zasoby }\end{array}$ & tak & tak \\
\hline 34. & $\begin{array}{l}\text { Liczba pracowników } \\
\text { z wyższym wykształceniem } \\
\text { bibliotekarskim / liczba pra- } \\
\text { cowników naukowych na } \\
\text { uczelni }\end{array}$ & $\begin{array}{l}\text { rentowność ma- } \\
\text { jątku, oferowa- } \\
\text { ne zasoby }\end{array}$ & nie & tak \\
\hline 35. & $\begin{array}{l}\text { Ogólna liczba zbiorów / } \\
\text { ogólna liczba potencjalnych } \\
\text { użytkowników }\end{array}$ & $\begin{array}{l}\text { rentowność ma- } \\
\text { jątku, oferowa- } \\
\text { ne zasoby }\end{array}$ & nie & tak \\
\hline 36. & $\begin{array}{l}\text { Liczba prenumerowanych } \\
\text { czasopism drukowanych } \\
\text { i elektronicznych / liczba } \\
\text { pracowników naukowych }\end{array}$ & $\begin{array}{l}\text { rentowność ma- } \\
\text { jątku, oferowa- } \\
\text { ne zasoby }\end{array}$ & nie & tak \\
\hline 37. & $\begin{array}{l}\text { Liczba nabytków / liczba po- } \\
\text { tencjalnych użytkowników }\end{array}$ & $\begin{array}{l}\text { rentowność ma- } \\
\text { jątku, oferowa- } \\
\text { ne zasoby }\end{array}$ & nie & tak \\
\hline 38. & $\begin{array}{l}\text { Liczba czasopism elektro- } \\
\text { nicznych / liczba czasopism } \\
\text { wpływających na bieżąco do } \\
\text { biblioteki (elektronicznych } \\
\text { i drukowanych) }\end{array}$ & $\begin{array}{l}\text { rentowność ma- } \\
\text { jątku, oferowa- } \\
\text { ne zasoby }\end{array}$ & nie & tak \\
\hline 39. & $\begin{array}{l}\text { Wydatki biblioteki na źródła } \\
\text { bibliograficzne / całość wy- } \\
\text { datków biblioteki }\end{array}$ & $\begin{array}{l}\text { rentowność ma- } \\
\text { jątku, oferowa- } \\
\text { ne zasoby }\end{array}$ & tak & tak \\
\hline 40. & $\begin{array}{l}\text { Wypożyczenia + wypożycze- } \\
\text { nia międzybiblioteczne reali- } \\
\text { zowane dla innych bibliotek } \\
\text { + usługa „Document deli- } \\
\text { very” dla innych bibliotek / } \\
\text { liczba zbiorów }\end{array}$ & $\begin{array}{l}\text { rentowność ma- } \\
\text { jątku, oferowa- } \\
\text { ne zasoby }\end{array}$ & tak & tak \\
\hline
\end{tabular}

Źródło: opracowanie własne na podstawie Prima Rilevazione Nazionale. Indicatori [online], [dostęp: 5.12.12], dostępny w internecie: http://www.gimsba.it/system/files/pub/rilevazioni/rilevazione2003/allegato-b-indicatori.pdf.

Po zakończeniu etapu doboru wskaźników opracowano kwestionariusze ankietowe. Podstawą badań miały być dwie różne ankiety, zintegrowane pod względem metodologii i czasu ich przeprowadzania. 
Pierwsza - „Questionario Biblioteca” (ankieta „Biblioteca”) - miała dotyczyć pojedynczych bibliotek. Spośród nich wyróżniono te działające w obrębie systemu SBA oraz tzw. monobiblioteki, czyli biblioteki funkcjonujące jako samodzielne jednostki administracyjne. Druga ankieta "Questionario Sistema Bibliotecario di Ateneo" (ankieta SBA) - dotyczyła funkcjonowania całości systemu: Sistema Bibliotecario di Ateneo. Wobec pojedynczych bibliotek i sieci bibliotek postanowiono zastosować różne zestawy wskaźników. (Inaczej postąpiono w Polsce, gdzie za pomocą jednego formularza ankietowego przeprowadzano badania dotyczące zarówno biblioteki głównej, jak i biblioteki głównej wraz ze wszystkimi bibliotekami sieci). Do stworzenia ankiet i administrowania nimi przez sieć posłużono się oprogramowaniem CreQue.

Pytania zawarte $\mathrm{w}$ ankiecie odnoszącej się do pojedynczych bibliotek umieszczono w siedmiu grupach tematycznych:

1. Informacje ogólne

2. Infrastruktura

3. Zbiory

4. Personel

5. Budżet

6. Usługi i godziny otwarcia

7. Użytkownicy pozainstytucjonalni.

Natomiast pytania zawarte w ankiecie dotyczącej systemu SBA obejmowały następujące grupy tematyczne:

1. Organizacja sieci

2. Jednostki koordynujące prace sieci

3. Źródła elektroniczne i automatyzacja usług

4. Zasoby ludzkie i budżet

5. Zbiory biblioteczne

6. Komentarz (pytanie otwarte).

Badania ankietowe zainicjowano 2 kwietnia 2003 roku rozesłaniem listów do rektorów 77 włoskich uczelni; na każdy list otrzymano odpowiedź. Następnie, kontaktując się telefonicznie z wyznaczoną osobą, ustalano listę bibliotek podlegających uczelniom, zamierzających wziąć udział w badaniu. Dzięki temu udało się stworzyć rejestr bibliotek akademickich funkcjonujących na terenie Włoch, który miał stanowić uzupełnienie kompleksowej bazy informacji na temat funkcjonowania bibliotek akademickich we Włoszech.

W rejestrze odnotowano 1378 bibliotek, w tym 17 tzw. monobibliotek, nietworzących systemu SBA. Z każdą biblioteką skontaktowano się 20 maja 2003 roku - wysłano list zawierający podstawowe informacje praktyczne, konieczne do wzięcia udziału w badaniu, oraz cele i metodologię 
badania. Powołano też call center, za którego pośrednictwem odpowiadano na wszelkie pytania dotyczące ankiety i rozwiewano wątpliwości.

Ustalono, że 14 lipca 2003 roku mija termin odsyłania ankiet z odpowiedziami, przesunięto go następnie na 1 sierpnia 2003 roku. Ostatecznie wypełnione ankiety nadesłało 1345 bibliotek. Wyniki badań oraz szczegółowy opis ich przebiegu zaprezentowano $\mathrm{w}$ witrynie internetowej organizacji GIM ${ }^{7}$.

Analizy zgromadzonych danych dokonano za pomoca oprogramowania SPSS, wersja 1.5. Po przeprowadzeniu badań niektóre wskaźniki zostały minimalnie zmodyfikowane, a trzech $\mathrm{z}$ nich nie obliczono. Raport końcowy prezentuje wyniki wszystkich obliczeń wskaźników wraz z opisem i wyjaśnieniem wszelkich wprowadzonych modyfikacji. Każdy $\mathrm{z}$ prezentowanych wskaźników jest opisany z uwzględnieniem następujących schematów: numer, nazwa, zadanie, źródło pochodzenia, interpretacja i czynniki oddziałujące na wskaźnik. Wartości dla każdego z obliczonych wskaźników są umieszczone w tabelach szeregujących biblioteki w kolejności: od wykazujących maksymalne do wykazujących minimalne wartości określonych wskaźników. Przy każdej tabeli podane są też: średnia wyniku, wartość środkowa i odchylenie standardowe ${ }^{8}$.

Drugą edycję badań grupa GIM przeprowadziła w 2006 roku. Przez cztery lata udało się w środowisku bibliotekarskim we Włoszech spopularyzować propagowane przez GIM praktyki. Lista uczelni organizujących analizy powiększyła się o następujące jednostki: Università degli Studi di Pavia, Università degli Studi di Perugia, Politecnico di Milano. Istotnym celem drugiej serii badań było ugruntowanie tradycji przeprowadzania regularnej oceny i porównywania jakości bibliotek akademickich na terenie całego kraju i dzięki temu umożliwienie bieżącej analizy dynamicznie zmieniających się tendencji w bibliotekarstwie. Drugiej edycji badań patronowała Conferenza dei Rettori delle Università italiane (CRUI, Konferencja Rektorów Akademickich Szkół Włoskich)9.

Kwestionariusze ankietowe miały taką samą strukturę jak podczas pierwszego badania. Różnicę stanowiły dodatkowe pytania w grupie tematycznej związanej z zasobami elektronicznymi, co wynikało z szybkiego rozwoju tej dziedziny w bibliotekach.

${ }^{7}$ Presentazione dei Risultati della Prima Rilevazione Nazionale GIM [online], [dostęp: 5.12.12], dostępny w internecie: http://www.gimsba.it/node/5.

${ }^{8}$ Misurazione e valutazione dell'offerta bibliotecaria degli atenei italiani [online], [dostęp: 5.12.12], dostępny w internecie: http://www.gimsba.it/system/files/pub/rilevazioni/rilevazione2003/relazione-finale.pdf.

${ }^{9}$ Rilevazione nazionale GIM 2007 [online], [dostęp 5.12.12], dostępny w internecie: http://www.gimsba.it/node/11. 
Podobnie jak za pierwszym razem do dyspozycji uczestników badania pozostawały call center oraz poczta elektroniczna. Odsetek nadesłanych odpowiedzi wyniósł w przypadku ankiety dotyczącej organizacji systemów SBA na uczelniach 91\%, natomiast w przypadku ankiet dotyczących działalności pojedynczych bibliotek $92,1 \%$, a więc wzrósł w porównaniu z pierwszym badaniem. Zauważono też, że respondenci udzielali dokładniejszych i pełniejszych odpowiedzi. Uczelnie, które odpowiedziały na mniej niż 30\% pytań zawartych w kwestionariuszu, wyłączono z badania. Aby umożliwić porównanie aktualnych wyników z wynikami uzyskanymi podczas wcześniejszego badania, wprowadzono współczynnik korekcji, równoważący brak uczelni biorących udział w pierwszej ankiecie, a wyłączonych z badania z powodu nieudzielenia wystarczającej liczby odpowiedzi. Do tych uczelni należały między innymi dwa duże uniwersytety: Università degli Studi di Roma „La Sapienza” oraz dell’Università degli Studi di Napoli „Federico II”. W ich przypadku zdecydowano się na zastosowanie zmiennej szacunkowej dla odsetka odpowiedzi udzielonych w poprzedniej ankiecie.

Obszerne wyniki przeprowadzonych badań, podobnie jak za pierwszym razem, zostały opublikowane $\mathrm{w}$ raporcie umieszczonym na stronie internetowej organizacji GIM ${ }^{10}$.

Trzecia, najnowsza edycja badań dokonanych przez GIM odbyła się w roku 2011. Badaniom towarzyszył proces sformalizowania grupy, uwieńczony podpisaniem przez 16 uczelni protokołu zawierającego zasady uczestnictwa w organizacji i konstytuującego cele jej działania (Protocollo di intesa per la costituzione e adesione al Gruppo Interuniversitario per il monitoraggio dei sistemi bibliotecari di ateneo). Powołano też Komitet Zarządzający, do którego zadań należy zatwierdzanie planu działań, rozpatrywanie wniosków innych uczelni o członkostwo w organizacji, udział w zewnętrznych projektach, zbieranie środków finansowych na realizację zamierzonych przedsięwzięć i kontrola kosztów. Ponadto komitet może tworzyć grupy robocze zajmujące się projektami szczególnymi i zapraszać do udziału $\mathrm{w}$ nich niezależnych ekspertów. Za szczególnie ważną uznano również rolę komitetu w promocji działań podejmowanych przez GIM oraz we współpracy z osobami z zewnątrz.

Na potrzeby trzeciej edycji badań została stworzona nowa ankieta nawiązująca do poprzednich kwestionariuszy, ale jednocześnie uwzględniająca ewolucję systemów bibliotecznych.

${ }^{10}$ Seconda Rilevazione Nazionale. Relazione Finale [online], [dostęp: 5.12.12], dostępny w internecie: http://www.gimsba.it/system/files/pub/rilevazioni/rilevazione2007/relazione-2006.pdf. 
Na stronie internetowej grupy GIM można zapoznać się z treścią listów wystosowanych do rektorów włoskich uczelni z prośbą o wzięcie udziału w badaniu, z formularzami ankietowymi (ankieta "Biblioteca” i ankieta SBA) oraz $z$ uwagami technicznymi ${ }^{11}$.

Badania przeprowadzane przez GIM wywarły istotny wpływ na pracę włoskich bibliotek akademickich. Doprowadziły do tego, że biorące udział w programie instytucje nie tyle konkurują o jak najlepsze wyniki, ile przede wszystkim współpracują ze sobą i dzielą się pomysłami. Działania podejmowane w ramach projektu GIM scalają biblioteki akademickie i wyznaczają kierunek ich wspólnych dążeń. Co istotne, w badaniach ważna jest zarówno ocena pracy poszczególnych jednostek, jak i ich współpraca w obrębie SBA. Osiągnięcie takiego stanu rzeczy wydaje się z punktu widzenia nie tylko polskich doświadczeń ważniejsze dla kształtowania bibliotek i praktyki ich funkcjonowania oraz zaspokajania potrzeb użytkowników niż samo wyznaczenie zespołu wskaźników.

Działalność organizacji GIM to jeden z wielu projektów badań funkcjonalności bibliotek akademickich w Europie i na świecie. Trudno wyobrazić sobie działanie współczesnych bibliotek oraz planowanie kierunku ich rozwoju bez uwzględniania tego rodzaju ważnych, wieloaspektowych analiz.

\title{
Studies on the functionality and operational efficiency of academic libraries in Italy - a case study of Gruppo Interuniversitario per il Monitoraggio dei sistemi bibliotecari di Ateneo
}

\begin{abstract}
Aвstract. Gruppo Interuniversitario per il Monitoraggio dei sistemi bibliotecari di Ateneo (GIM) is an Italian intercollegiate organization that, since 2000, has been involved in conducting regular statistical studies related to the functionality and operability of Italian academic and research libraries. The group is composed of representatives from 16 outstanding Italian universities: Alma mater studiorum di Bologna, Politecnico di Milano, Politecnico di Torino, Università degli studi dell'Insubria, Università degli studi di Ferrara, Università degli studi di Firenze, Università degli
\end{abstract}

${ }^{11}$ Rilevazione nazionale GIM 2011 [online], [dostęp: 5.12.12], dostępny w internecie: http://www.gimsba.it/node/24. 
studi di Milano, Università degli studi di Milano Bicocca, Università degli studi di Modena e Reggio Emilia, Università degli studi di Padova, Università degli studi di Parma, Università degli studi di Pavia, Università degli studi di Perugia, Università degli studi di Sassari, Università degli studi di Siena and Università degli studi di Trento. The results of their studies are prepared in a report available on the internet web page of the GIM. The results are constantly validated in a database on the operation of present-day Italian academic libraries and thus deliver interesting data useful to formulate sustainable development objectives. The database provides comparative studies that make it possible to establish what the current developmental tendencies in the provision of library services are in the country and to indicate possible solutions to be taken in order to introduce further improvement in the field. This article attempts to provide an overview of the activity of the organization for the past several years and to present the most important premises of the project. Additionally, the article discusses the research methods used in Italy and shows how the initiatives undertaken currently fit in into a broader context of studies on the functionality of libraries in other countries in Europe, including Poland.

KEY wORDs: studies of the functionality of libraries, standards in evaluation of libraries, modern Italian libraries. 
